\section{An Investigation of Sustainable Transportation Model in Campus Areas with Space Syntax Method}

\section{Abstract} Purpose

Campus areas should be designed as centers where social activities can be fulfilled to meet students' needs, and which can serve the society by promoting sustainability. Nowadays, transportation systems (bike path, public transport, etc.) that support sustainability are not very common in campus areas. This situation leads to many environmental, economic and social problems. Therefore, it is extremely important to develop sustainable transport plans to uncover the current state of the transport system and to meet future transport needs. In the study, it was aimed to compare the spatial characteristics of Kilis 7 Aralik University's current situation and its design in line with sustainable transportation principles.

\section{Design/Methodology/Approach}

This study was carried out in the central campus of Kilis 7 Aralik University. In the study, the existing transportation infrastructure of

\section{Ahmet Salih Günaydın* Murat Yücekaya $^{* \star}$}

Keywords: Green campus, Kilis 7 Aralık University (KIYU), space syntax, sustainability

*Assist. Prof. Dr. Inonu University Faculty of Art and Design Department of Landscape Architecture, Malatya, Turkey

Email: ahmetsalihgunaydin@gmail.com ORCID No: https://orcid.org/00000001-5799-0445

${ }^{* *}$ Assist. Prof. Dr. Nevsehir Haci Bektas Veli University Faculty of Engineering and Architecture Department of Landscape Architecture. Nevsehir, Turkey

Email: muratyucekaya @nevsehir.edu.tr ORCID No: https://orcid.org/00000003-2072-712X 
the campus has been evaluated, a sustainable transportation model has been formed in accordance with the concept of "green campus," and changes in spatial characteristics of the campus with the environmental, physical and social contributions of this model have been explained. Spatial composition method was used to analyze the spatial properties.

\section{Findings}

In the sustainable design model, while the local integration value decreased, global integration, intelligibility, accessibility, and synergy values were found to increase.

\section{Research Limitations/Implications}

In the study, the sustainable transportation model was carried out in a narrow area, such as the campus area. It is thought that the results obtained will be the basis for the studies to be carried out in larger areas.

\section{Practical Implications}

Campus accessibility, intelligibility and global integration values have increased with the sustainable transportation model. This situation is expected to increase the livability of campus areas.

\section{Social Implications}

It is thought that the mental health and academic achievements of the campus users will be positively affected in the campuses designed with the planning approach based on the sustainable transportation model.

\section{Originality/Value}

The article is considered important in terms of examining sustainable transportation in campus areas compared to spatial analysis.

\section{INTRODUCTION}

Many countries around the world are trying to take precautions to solve global and local problems such as rapid urbanization, climate change, social inequality, poverty, biodiversity loss, overpopulation and lack of resources. The first step towards resolving these problems is Our Common Future Report (Brundtland Report), which was published in 1987 by the World Commission on Environment and Development (WECD). The most important feature of this report is that it introduced the concept of sustainability. In general, sustainability is defined as the ability of future generations to meet their current needs without compromising the competence to meet their current needs (B. Patel \& P. Patel, 2012; Rodwell, 2003). Its main objective is to reduce the available resource consumption and expand the resource production limit (Amr et al., 2016).

Sustainability is about how a community at various levels of the society predicts and maintains its social, economic and ecological well-being (Mohamad et al., 2018). It is no doubt that universities are among the key examples of these communities. Universities are not only considered small communities because they offer dense populations and complex services, but they also play a vital role for a sustainable future in the education system 
(Gu et al., 2018). Efforts to manage environmental problems of university campuses and to promote social change are called campus sustainability (Washington-Ottombre et al., 2018). The sustainability of the campus expresses the ways in which campus communities create a sustainable vision for the future and plays an important role in researching potential pathways by discussing the vision and values they represent (Miller et al., 2011). Sustainable university is also known as green university, green campus and eco-campus (Günerhan, 2016).

University campuses are separated from the cities and other regions that make up the city in terms of their missions, objectives and managerial formation. Campus areas should be designed with a concern to create an environment that supports learning. The physical characteristics of campus areas should improve students' life quality and help them manage the challenges of academic life (Dyson \& Renk, 2006). A welldesigned green campus can reduce students' mental fatigue levels by encouraging them to socialize in their spare time and increase their perceptions in the social context. Previous studies have shown the relationship between students' attitude and environmental factors (Berger \& Braxton, 1998; Lounsbury \& DeNeui, 1996; Roberts \& Styron, 2010).

In the last 50 years, various studies have been conducted on sustainability of campus areas, communities have been formed and declarations have been signed. The first of these was to draw attention to environmental protection education in 1972 at the Human Environment Conference in Stockholm. In 1990, the University Leaders for a Sustainable Future (ULSF) association signed the Talloires Declaration, which identifies the ten steps to be followed for sustainability, and which was signed by more than 500 colleges and university leaders in more than 40 countries worldwide (Tan et al., 2014; ULSF 2019.). This declaration was one of the most important foundations for sustainable universities. In 1993, the Kyoto Declaration compelled universities to promote sustainability by reviewing its activities, which would place higher education institutions to the foundation of sustainable development practices (IAU, 1993). In 2011, a guide to the design of sustainable university campuses was prepared headed by Greening Universities Initiative which was founded by the Global Universities Partnership for Environment and Sustainability (GUPES), United Nations Environment Program (UNEP) and the Environmental Education and Training Unit (EETU) (Oktaya \& Küçükyağcl, 2015) .

Sustainability is a major element of transportation considering its resource consumption, environmental, economic, and social impacts. Latest developments in automobile industry has rapidly contributed to societal improvements. Yet, it has also caused 
many problems that has negative social, economic and environmental effects like dense traffic, noise, pollution, loss of natural resources, incorrect land utilization, and damage to property and life due to accidents (Schiller et al., 2010).

The contribution of sustainable transportation model to the solution of social, environmental and economic problems has been discussed in many study conducted until today (Azapagic \& Perdan, 2000; Demiroğlu et al., 2018; Litman \& Burwell, 2006; Lukman et al., 2009; Mohamad et al., 2018; Oktaya, 2015; Olszak, 2012; B. Patel \& P. Patel, 2012; Schiller et al., 2010; Wey \& Huang, 2018). However, it has been observed that the studies on the social dimension of sustainable transportation model in urban context are fewer in the literature. Thus, this study focused on the social changes of the sustainable transportation model in campus areas rather than its economic and environmental contributions. Space Syntax method was used to determine the changes in the social dimension, in other words, to identify and quantify the changes in its spatial characteristics (Accessibility, Intelligibility and Synergy). Space syntax is a method developed by Bill Hillier and his team in the 1970s to identify and analyze spatial organizations from residential scale to urban scale. The aim of this method is to demonstrate the extent to which the spaces are used and the relationship between social variables and architectural forms with an objective and precise definition (Hillier et al., 1983). One of the most important features of the method is that it can visually demonstrate how the new designed spatial models work, compare the old and the new ones, predict the future problems to a degree in small or large scale planning and design studies, and allow making planning and design in line with these problems (Kubat, 2015). The method differs from other methods in that it reveals the possible effects of the designs through mathematical values. This methodology is expected to contribute greatly to the understanding of the physical structure of the design created in this study.

This study was carried out in Kilis 7 Aralık University Central Campus (KIYU).In the study, the existing transportation infrastructure of the campus has been evaluated and a sustainable transportation model has been formed in accordance with the concept of "green campus" and this model's all possible contributions to the environment from social aspects and the changes in its spatial characteristics have been identified.

\section{METHODOLOGY}

\section{Research Case}

The main material of the study is the KIYU central campus. Kilis city is in $36^{\circ} 45$ 'and $37^{\circ} 45^{\prime}$ north latitudes and $37^{\circ} 00$ 'and 36 
${ }^{\circ} 45$ ' east longitude. Kilis is neighbor to Antakya in the west and Gaziantep in the north. Turkey-Syria border is in the southern part of the city. The campus is in city center in north-west direction. The university campus has 5 faculties, 2 vocational schools, President's Building, Central Laboratory, Mosque, Library-Congress Center, Technical Departments and various social, cultural and sports areas (Figure 1).

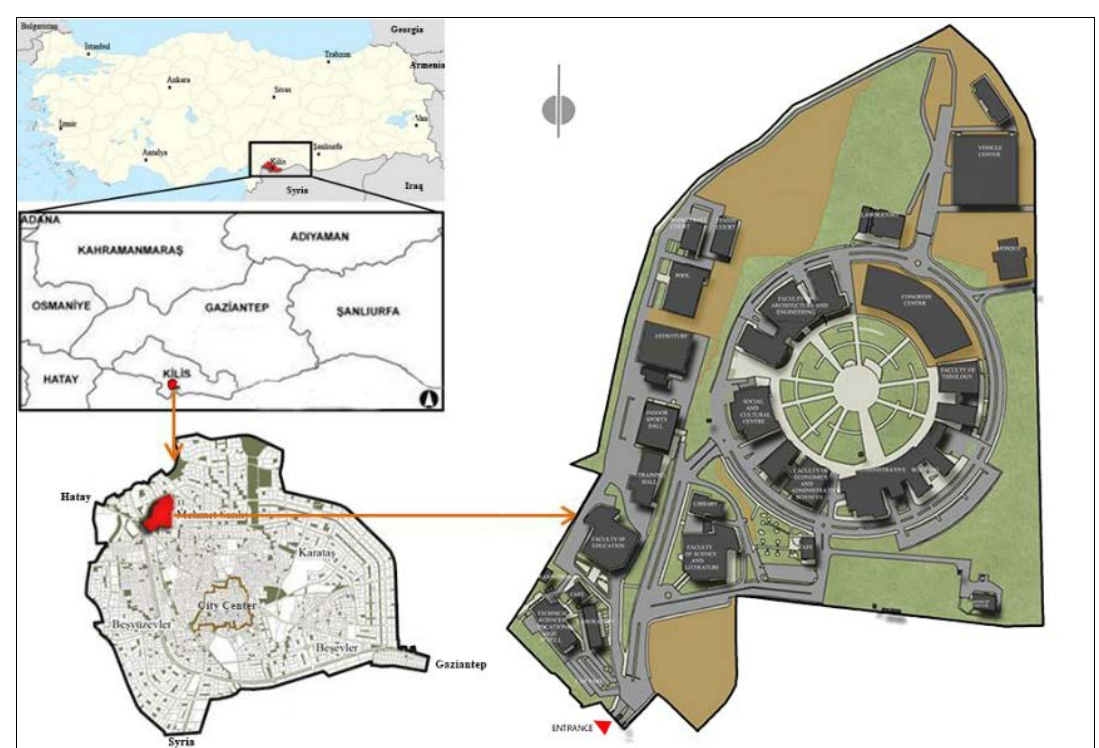

\section{Space Syntax}

The space syntax sequence is a set of techniques that analyze the relationship between spatial structures and the societies that make it up according to some theories from residential scale to urban scale(R. C. Dalton \& N. S. Dalton, 2007). Space syntax is a graphical model based on dynamic and static measurements (Hillier et al., 1987). The spatial system is represented with the shortest and longest lines that define all gaps in the urban area in the graphs. The map created by these lines is called the axial map (Jeong et al., 2015). After axial maps are converted to graphs and topological (non-metric) analyses, a model based on the linear link called "integration" was created (Hillier, 1999). Integration maps describe how both vehicle and pedestrian movements work within the urban system, and they are important to understand how often public spaces are used (Hillier, 2007). Hillier, 1998, 1999; Hillier \& Iida, 2005; Li et al., 2016; Özbil et al., 2013; Özer \& Sema, 2014 have demonstrated the relationship between movement and integration values in their work. Integration is a static global measurement (Klarqvist, 1993) and shows accessibility spatially, not in metric terms. It also defines the average depth of a space in the system compared to all other spaces. Total depth (TD) is calculated by summing the depths via
Figure 1. Geographical location and current state of the campus 
each of the shortest paths between one segment and all others in a street network; $\mathrm{TD}_{\mathrm{x}}=\sum_{\mathrm{i} E \mathrm{~s}, \mathrm{i} \neq \mathrm{x}} \mathrm{D}(\mathrm{x}, \mathrm{i})$ (Jeong et al., 2015).

The Integration is as follows: $\mathrm{I}_{\mathrm{x}}=\frac{\mathrm{NC}^{\mathrm{z}}}{\mathrm{TD}_{\bar{x}}}$ where Ix denotes the integration value of space $\mathrm{x}$, and NC indicates the node count (i.e., the number of nodes within a radius to be analyzed) in a street network regarded as a graph consisting of a set of nodes and a set of edges (Jeong et al., 2015). The integration value has two different measurements. The first is the Global integration value (Rn), which takes into account all the other nodes within the system; the second is the Local integration value, which defines the connection density of a node with the three-step (R3) depth nodes in the system (Dettlaff, 2014; Gann, 2003; Hillier, 2007).

One of the basic analyses of the space syntax method is integration analysis. However, other analyses such as connectivity and choice can also be conducted. While integration and connectivity are static measurements, choice is a dynamic measurement (Al_Sayed et al., 2012). Connectivity is the numerical expression of spaces that can be directly connected to another space (Klarqvist, 1993). Choice refers to the probability of the selection of lines that can be passed in order to go to another line in the system (axial line) (Hillier, 2005). Correlation is established between these measurements obtained by using the spatial syntax, and then, characteristic features of the space such as Intelligibility, Accessibility and Synergy can be fully explained.

The intelligibility of a space refers to the relationship between its integration and connectivity values. If the integration values is high in the lines that are connected locally, the correlation between them will be strong and the system will be understandable. Conversely, if the integration values of wellconnected lines is low, the correlation will be weak and the whole will not be understood from the parts. Integration and choice value are two important parameters in accessibility. The correlation between these two values gives us how accessible the space is. To clarify, the correlation between these two variables indicates the degree of a space's movement potential and its moving potential.

Hillier at all. (1987) describe the concepts of intelligibility and accessibility as follows;

"Intelligibility is quantified as a second order measure and it is defined as the degree of correlation between connectivity and global integration values of the axial lines in spatial configuration analysis. It indexes the degree to which the number of immediate connections a line has - which can therefore be seen from that line - are a reliable guide to the importance of that line in the 
system as a whole. If locally well-connected lines are also integrating lines, then the correlation will be strong, and the system will have "intelligibility". The whole can be read from the parts. Conversely, if well connected lines are not also integrating lines, then the correlation will be poor, and the whole will not be readable from the parts. Equally suggestive is the degree of correlation between the "global state" measure (integration) and "global dynamic" measure (choice). The correlation between these two variables will indicate the degree to which the accessibility of a space as a destination from all others (how many steps it is away from all other spaces in the layout) is a reliable guide to its likely popularity as a space to be passed through on shortest routes from all points to all other points in the layout. More simply, it indexes the degree of agreement between a space's potential for to-movement and throughmovement" (Bill Hillier et al., 1987). Synergy, which is similar to intelligibility in many respects, is the correlation coefficient between local (R3) and global (Rn) integration (Dalton, 2010; Hillier, 2001; Sayed, et al., 2014). There are many study that have analyzed intelligibility, accessibility and synergy by using the space syntax method (Asami et al., 2001; Hillier, 2001; Park, 2009; Dalton, 2010; Legeby, 2013; Sayed, et al., 2014; Ugalde et al., 2009; Zhang et al., 2013; Topçu, 2019).

\section{Analytical Framework}

The study focused on the comparison of spatial analysis based on the current plan of the KIYU central campus and the spatial analysis as a result of the new planning based on the sustainable transportation model. The study was carried out in three stages: current situation analysis, design and analysis based on sustainable transportation planning, and comparison of the spatial features resulting from these two designs.

The first part of the study, necessary changes and drawings were made on the existing map of KIYU central campus and current Axial map was created. Then, this axial map was analyzed with the help of DephtmapX software, integration, connectivity and choice maps were created in global and local (R3) scale. The intelligibility, accessibility and synergy analyses were conducted based on these maps. As a result of these analyses, the current spatial situation of KIYU central campus was revealed.

In the second part of the study is based on the sustainable transportation model of the central campus. In this part of the study, the existing usage and transportation infrastructure has been identified based on the current plan of KIYU central campus obtained from directorate of construction and technical works. In the last section, a sustainable transportation model of the campus area has been formed based on the literature. Public 
parking spaces are created in this model and the use of private vehicles is restricted within the campus area. In this transportation model, Standards for the Design and Construction of Bicycle Roads, Bicycle Stations and Bicycle Parking Places on Intercity Roads have been used (Official Gazette, 2015) (Figure 2). An axial map of the new model was created based on this planning. This axial map was analyzed in DephtmapX software, and integration, connectivity and choice maps were created in global and local scale. The intelligibility, accessibility and synergy analyses of the new model were conducted using these maps.

By comparing the results obtained with the space syntax method, which allows comparison of the current situation and the situations in which the recommendations are developed, this study seeks answers on how intelligibility, accessibility and synergy values are affected based on sustainable transport system model. The flow chart of the method is shown in Figure 2.

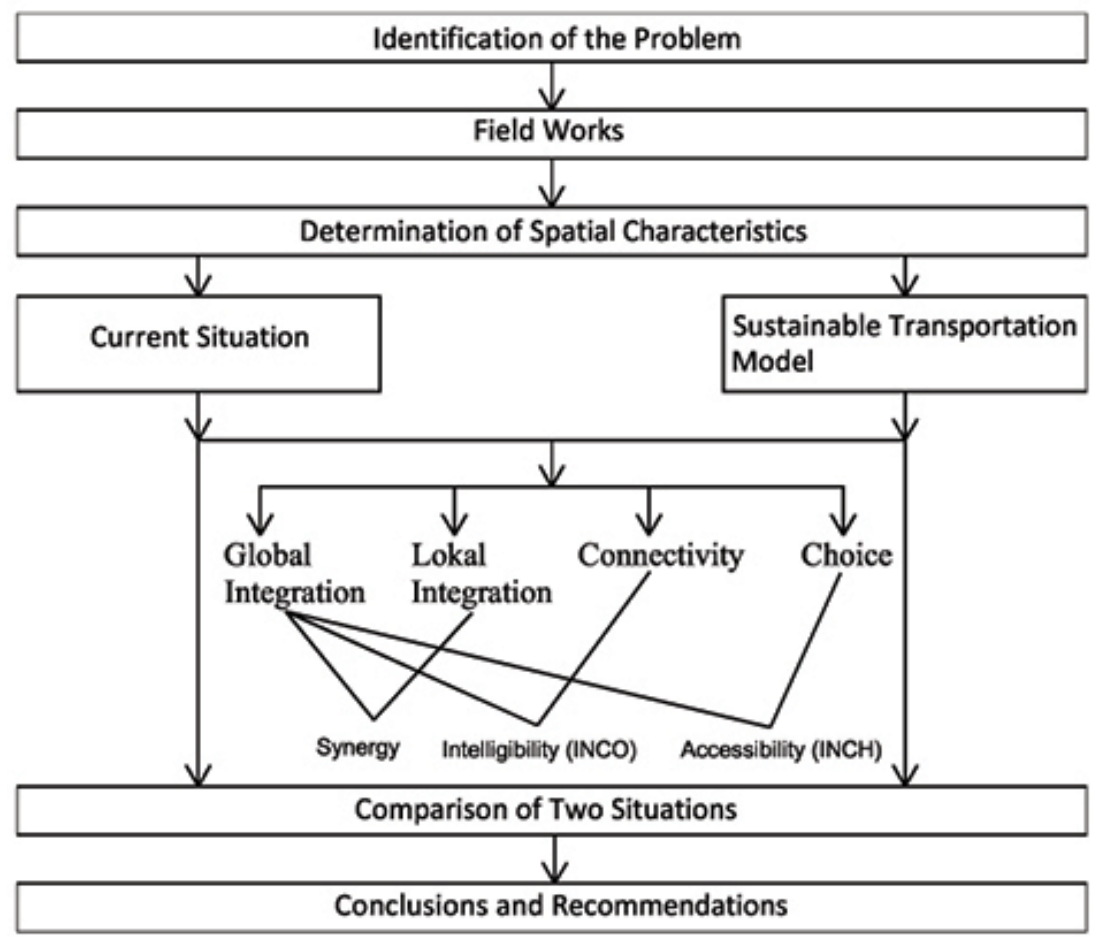

\section{RESULTS AND DISCUSSIONS}

\section{Sustainable Transportation Model}

Situated within approximately $256,000 \mathrm{~m}^{2}$ of land, the campus' current situation is given in Figure 1 and Table 1. \%31.70 of the campus is covered with green areas, followed by $\% 18,82$ vehicle ways, $\% 17,42$ building area, $\% 17,37$ soil area and $\% 11,81$ pedestrian path. 200 administrative staff, 290 academic staff and 6900 students, 7390 people in total currently use the campus area (KIYU Personnel Department, 2018; KIYU Registrar's Office, 2018). 2 gates are actively used to enter and leave the campus. 
Approximately 1000 vehicles enter and exit the campus per day according to 2018 data.

The main transportation axes planned based on the section in the campus is given in Figure 4 and sustainable transportation model of the campus created based on relevant literature is given in Figure 3.

In the model, it is recommended not to use the main transport axes and vehicle roads which are planned to be used to enter the building except emergency situations. Two different locations are recommended in campus entrances, including bicycle maintenance / rental services and battery-powered vehicles for disabled users. In addition, the parking spaces between the buildings were removed and these areas were planned as green areas in the model (Figure 3). By building car parks near the campus gate, the vehicle traffic to the camp was limited to approximately 1000 cars per day (Figure 4). It is recommended that no motor vehicles should not enter the campus except in emergencies.
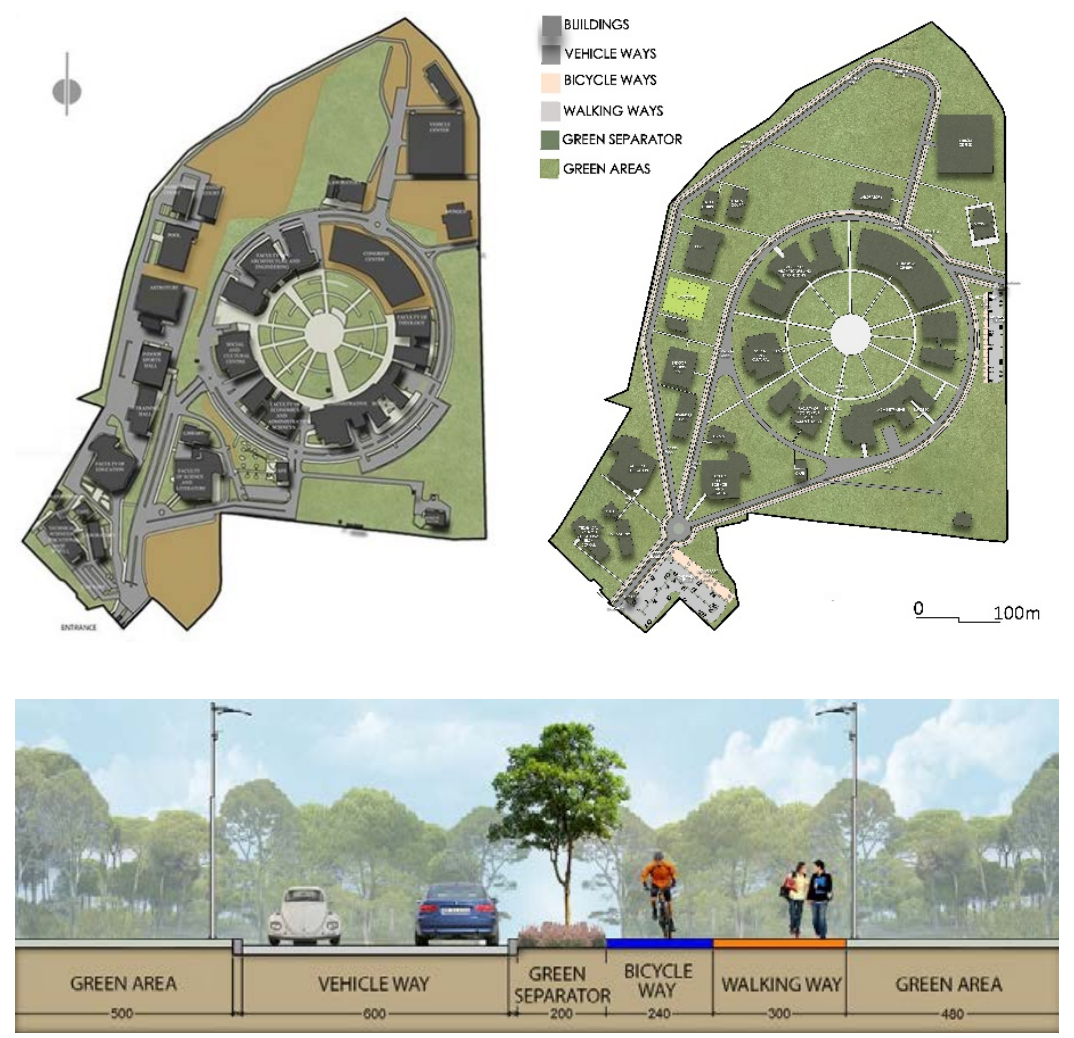

By making the following changes in the existing campus master plan, a sustainable based campus master plan was created.

- All of the car parks between and around the building have been removed and converted to green areas.

- A wide central square is created after the main entrance and distribution to all roads is provided from this area.
Figure 3. Campus Master Plan. Left Current Stuation, Right Sustainable Transportation Model

Figure 4. Recommended road section for the sustainable transport model (Demiroğlu et al., 2018). 
- The idle space at campus entrance has been converted to a car park, and the areas in the north are still under development and planned as green areas.

- All of the nonfunctional hard floors on the campus have been turned into green areas.

- Pedestrian paths have been planned in such a way that they can form gathering-dispersion spaces, provide the main circulation and provide access to faculty buildings.

- In the sustainable transportation model, only service roads or emergency roads have been designed with double lanes instead of current double lane roads.

Table 1. Current land area usage rates and rates after suggestions inside the campus

\begin{tabular}{|c|c|c|c|c|c|}
\hline & $\begin{array}{c}\text { Current } \\
\left(\mathrm{m}^{2}\right)\end{array}$ & $\begin{array}{l}\text { Rate } \\
(\%)\end{array}$ & $\begin{array}{l}\text { Proposed } \\
\left(\mathrm{m}^{2}\right)\end{array}$ & $\begin{array}{l}\text { Rate } \\
(\%)\end{array}$ & $\begin{array}{c}\text { Inc. and } \\
\text { decr. rates } \\
(\%)\end{array}$ \\
\hline $\begin{array}{l}\text { Green } \\
\text { space }\end{array}$ & 81.08 & 31.70 & 142.2 & 55.60 & 75.38 \\
\hline Soil Area & 44.42 & 17.37 & 31.65 & 12.37 & -28.75 \\
\hline $\begin{array}{l}\text { Vehicle } \\
\text { path }\end{array}$ & 48.14 & 18.82 & 17.36 & 6.79 & -63.94 \\
\hline Car Park & 7.36 & 2.88 & 7.99 & 3.12 & 8.56 \\
\hline $\begin{array}{l}\text { Pedestrian } \\
\text { path }\end{array}$ & 30.21 & 11.81 & $\begin{array}{l}7.11 \\
\mathrm{~km})\end{array}$ & 2.78 & -76.46 \\
\hline $\begin{array}{l}\text { Bicycle } \\
\text { path }\end{array}$ & 0 & 0.00 & $\begin{array}{ll}4.9 & (2.3 \\
\mathrm{km}) & \end{array}$ & 1.92 & 1.92 \\
\hline $\begin{array}{l}\text { Building } \\
\text { Area }\end{array}$ & 44.56 & 17.42 & 44.56 & 17.42 & 0 \\
\hline Total & 255.77 & 100.00 & 255.77 & 100.00 & \\
\hline
\end{tabular}

The vehicle roads have been reduced from $48.140 \mathrm{~m} 2$ to 17.360 $\mathrm{m} 2$ in the campus area with this plan. Green areas increased to $142,202 \mathrm{~m} 2$ from $81,088 \mathrm{~m} 2$. The aim here is to reduce greenhouse gas emissions and support biodiversity. In addition, a $2.3 \mathrm{~km}$ cycling route and $5.4 \mathrm{~km}$ walking path has been designed in the plan. The highest increase occurred in green area, the highest decrease was in pedestrian and vehicle roads. Thus, sustainable campus design, which constitutes the main hypothesis of the study, was attempted to be realized.

The activity areas designed for university students on campuses are important to spend their free time effectively. These areas increase the social development of students by decreasing their social oppositional behaviors and contribute positively to reduction of drug addiction and crime rates (Kuo \& Sullivan, 2001; UN-HABITAT, 2008). Therefore, it is aimed that these areas contribute positively to campus users in term of issues like social cohesion, integration and physical health. Hipp, Gulwadi, Alves, \& Sequeira, (2016) highlighted the physical and psychological positive effects of green areas on students in their study. 
Comparison of Sustainable Transportation Model and the Current Situation in terms of Spatial Features

While preparing the campus transportation plan, current complex transportation planning has been simplified as far as possible. This is the reason for approximately $\% 40$ decrease in the number of axial lines. The campus access is provided via three main axes starting from the entrance in the proposed campus transportation network map. Central axis that provides access to the circular center area and lines that are connected to this line are the axes with the highest integrated value in the area. There was an approximately $\% 12$ increase in Average Global integration value with this proposed transportation plan (Figure 5, Table 2).
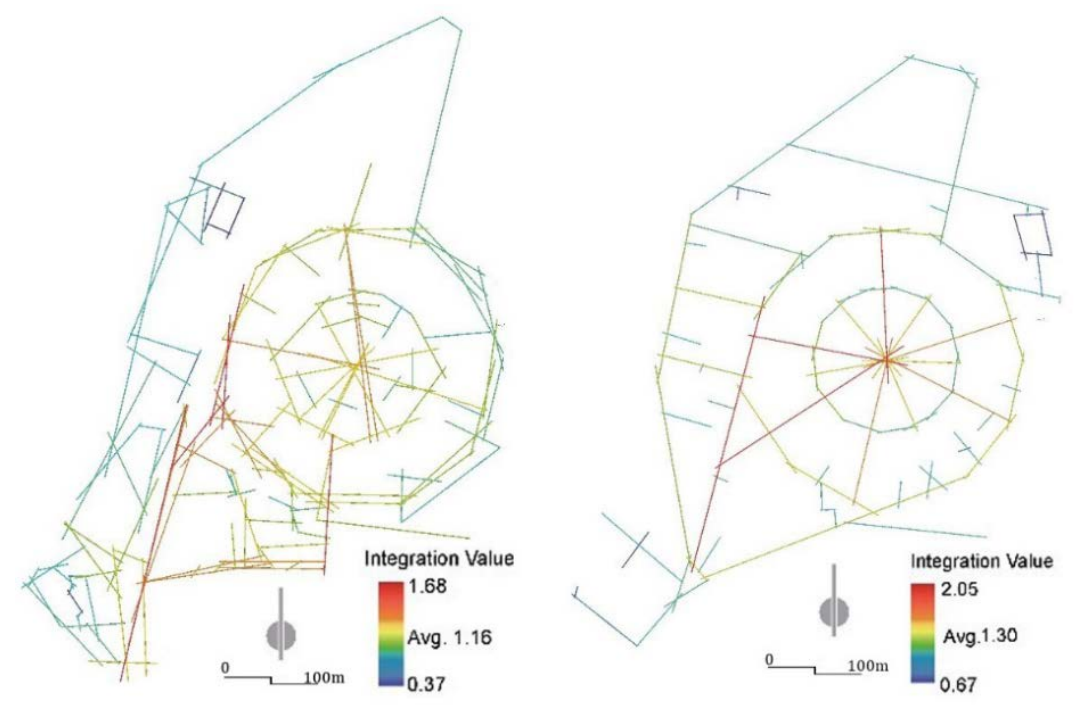

The integration values of the current transport network in the R3 radius were higher. This situation is normal because the current transportation axes are large in number. However, the radial axes expanding outwards from the main center in the proposed transport map have high integration value. There was a \%18 increase in the proposed map compared to current map considering the synergy graphs obtained from the correlation of Rn integration and R3 integration values (Figure 6-7, Table 2).
Figure 5. Global integration map. Left existing state, right proposal plans 
Figure 6. Local integration map (R3). Left existing state, right proposal plans

Figure 7. Existing state and proposal plans synergy graphs
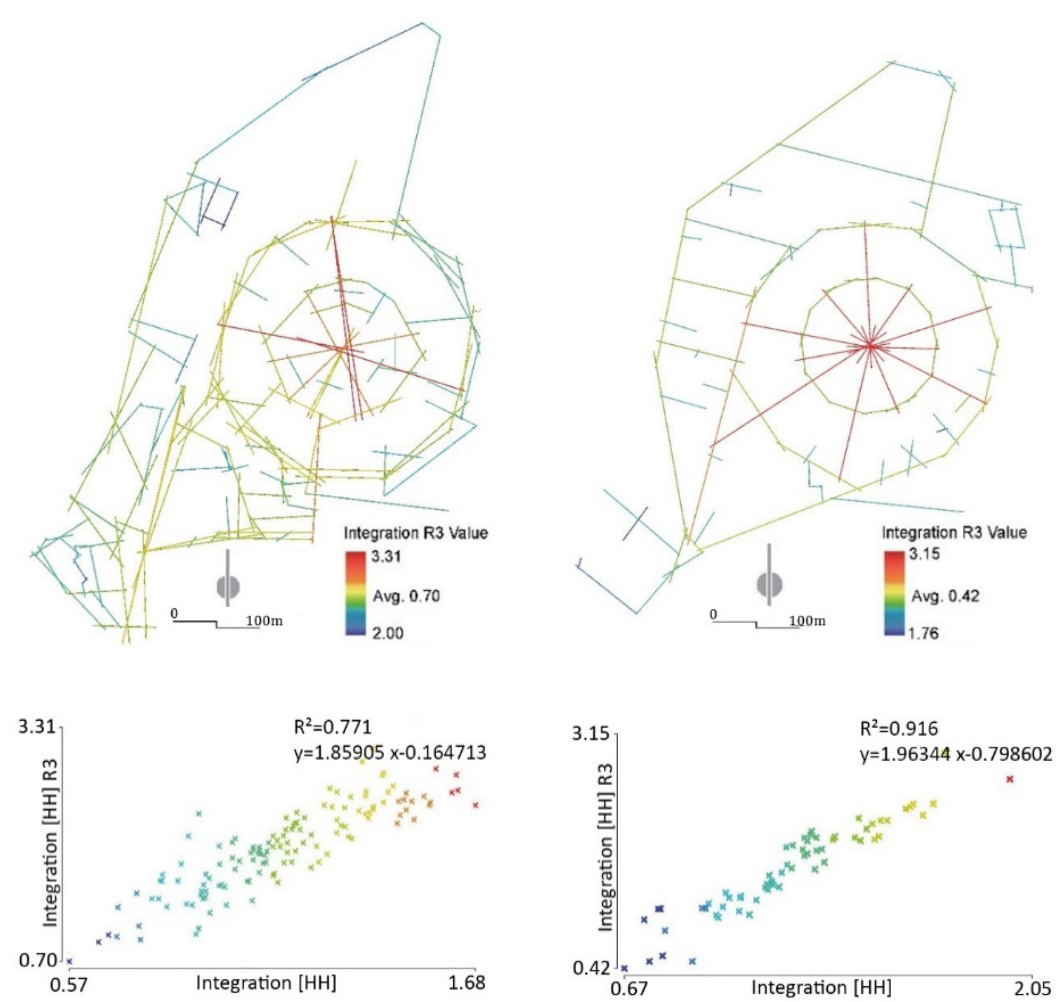

The average connectivity values are approximately \%25 higher in the current situation (Figure8). However, there are approximately \%21 increase in the proposed plans in the intelligibility charts (Figure 9). This situation can be interpreted as current situation's having a high level of connectedness and choice alternatives, but that intelligibility and accessibility can be increased by more simple, functional and purpose-oriented designs.

In the same way, while average choice values in the choice maps (Figure 10) are less than half of the proposed plan compared to current situation, the accessibility as the definition of correlation graphs of the choice and integration values showed an approximately \%62 increase (Figure 11, Table 2). 

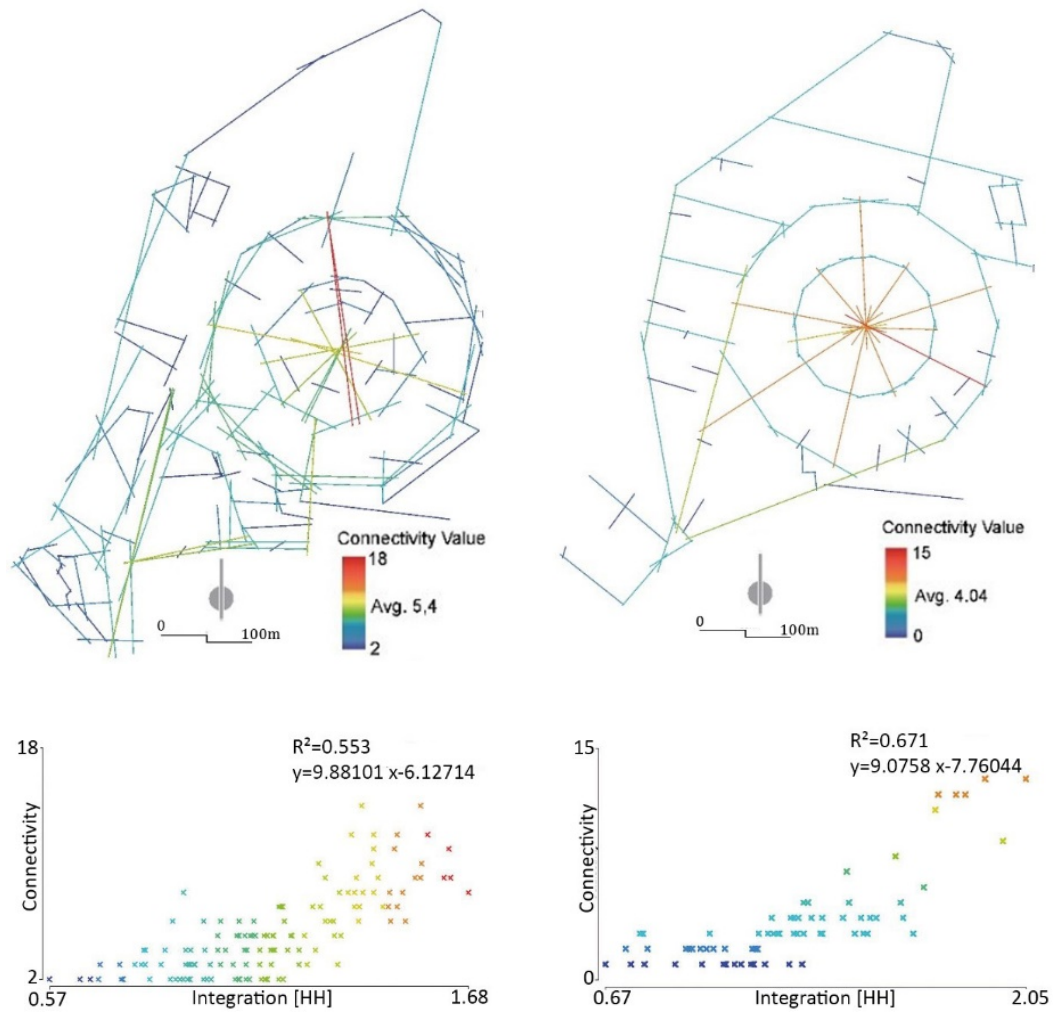

274

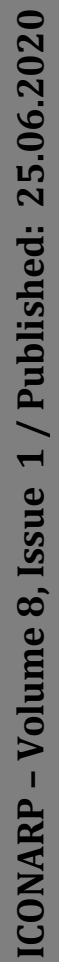

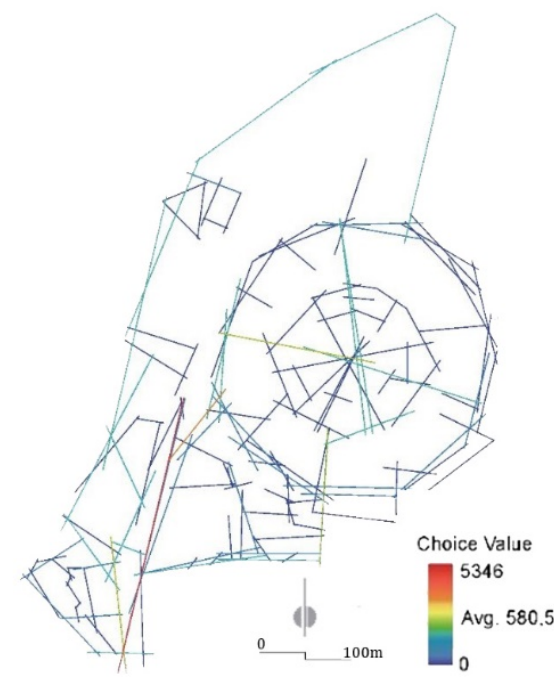
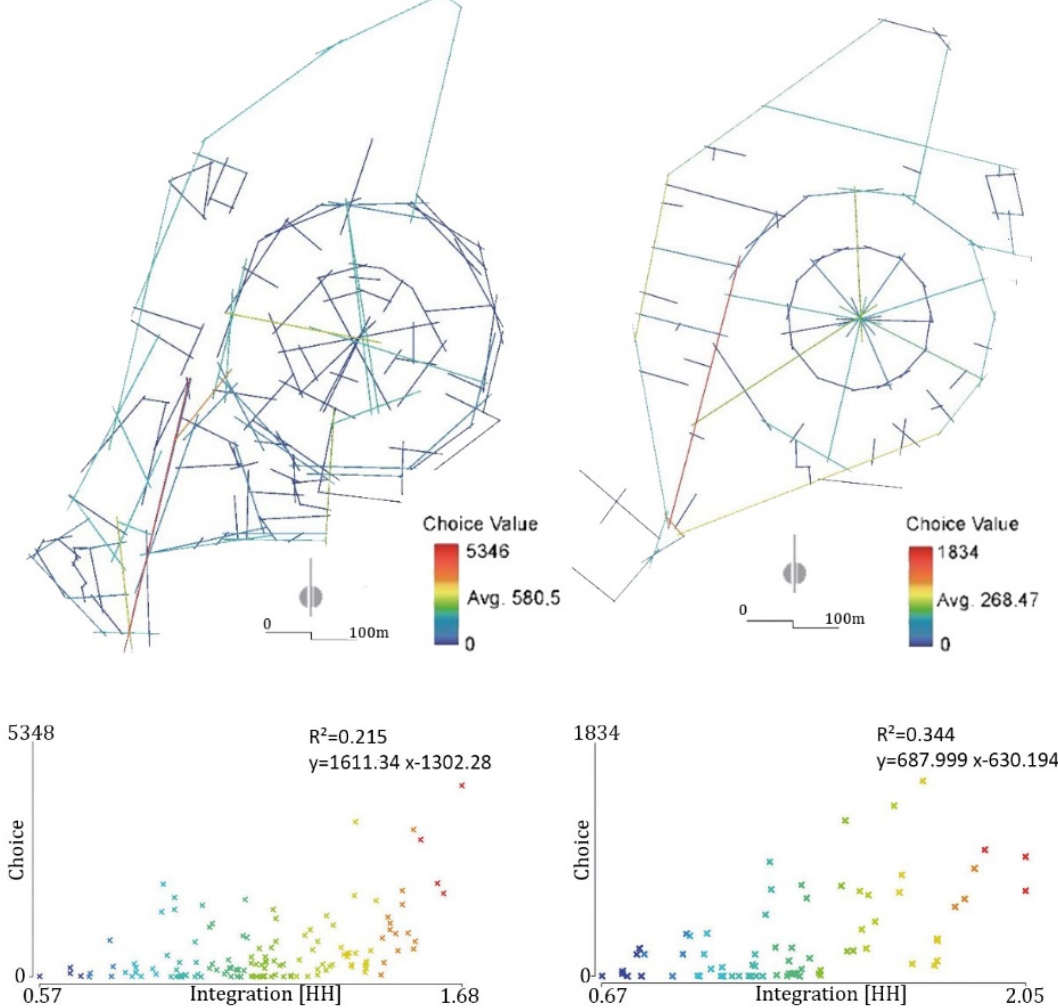

The changes in spatial characteristics as a result of proposed sustainable transportation model are given in Table 2 .
Figure 8. Existing state and proposal plans connectivity maps

Figure 9. Existing state and proposal plans intelligibility graphs

Figure 10. Existing state and proposal plans choice maps

Figure 11. Existing state and proposal plans accessibility graphs 
Table 2. Comparison of the current spatial characteristics of the campus area and the spatial characteristics after the proposal

\begin{tabular}{llll}
\hline & Current & Propose & Inc.-Dec. Rate (\%) \\
\hline Axial line & 141 & 85 & -39.72 \\
\hline Global Integration (Rn) & 1.16 & 1.30 & 12.07 \\
\hline Local Integration (R3) & 0.70 & 0.42 & -40.00 \\
\hline Intelligibility (INCO) & 0.55 & 0.67 & 21.81 \\
\hline Accessibility (INCH) & 0.21 & 0.34 & 61.90 \\
\hline Synergy & 0.77 & 0.91 & 18.18 \\
\hline \multicolumn{2}{c}{ INCO: Correlation of Between Integration and Connectivity } \\
INCH: Correlation of Between Integration and Choice
\end{tabular}

As a result of the analyses, it is seen that there is an increase in global integration, intelligibility, accessibility and synergy features of the campus area but a decrease in the local integration value. The cause of these reductions might be the decrease in the connectivity values and the number of axial lines. As Hillier, Penn, Hanson, Grajewski, \& Xu, (1993) stated, "higher levels of integration necessitate more network connections. A more integrated space is shallower on average, whereas a less integrated space is on average deeper." This definition is in line with the results of this study.

The study differs from previous sustainable transportation model studies in the literature with its focus on spatial characteristics. As stated at the beginning, while the studies based on sustainable transportation model generally deal with its contributions to social, economic and environmental problems, this study is important in that it examines the contribution of sustainable transportation model to spatial characteristics. Balsas, 2003; Demiroğlu et al., 2018 have demonstrated the contribution of sustainable transportation model to campus areas in their studies. As a result of this study, it has been observed that the campus design based on sustainable transportation model contributes positively to spatial characteristics such as intelligibility, accessibility and synergy as well as its economic, social and environmental benefits. However, this study does not claim that all designs based on sustainable transportation model will always contribute to spatial characteristics. To make such a claim, more studies should be done, and the subject should be addressed in a broader sense.

\section{CONCLUSION}

This study carried out in KIYU campus aims to identify the changes caused by sustainable transportation model on intelligibility, accessibility and synergy levels. Based on this model, a new planning model is proposed that restricts private vehicle usage and supports cycling and walking activities. With this model, adverse effects of economic, social and environmental problems resulting from using motor vehicles as 
specified by Schiller et. al., (2010) will be reduced and thus, sustainability goals stated at Litman (2011) will be achieved.

The study presupposes that campus planning is important for campus users. The space syntax method was used to provide more specific suggestions to the question of how to design campus areas. It is argued that designs to be made using the space syntax method and sustainable transportation model can improve the spatial characteristics of campus areas.

As a result of the findings obtained from this study, it is claimed that a campus area, which has a good spatial character, that is which is formed with perceived and accessible spaces, will contribute positively to students' academic success and mental health. Therefore, the physical campus should be designed and managed as an environment that will reduce student's mental fatigue and improve life quality and academic performance. For this reason, the university management should make a sustainable campus area as a basis for research and teaching and should strive to preserve natural resources and support sustainable use in a way that ensures the environmental health and safety of the university community.

Sustainable planning can be examined under many subheadings. This study evaluates the effects of transportation-oriented sustainable design at university campus scale. Further studies might be carried out by using detailed sustainable design principles from other various fields. It is considered that the study might open new paths for more detailed studies to be carried out in the future.

Campus planning is a complex and multidisciplinary process that requires more and more actors to communicate with each other. Higher data requirements, different methods, accepted assumptions and limitations should be carefully considered by planners in the planning processes. Indicators evaluating the spatial characteristics of campus areas such as accessibility and intelligibility represent quite useful agents for developers and might provide campus managers with sound policies to create more livable and healthier campus environments.

\section{REFERENCE}

Al_Sayed, K., Turner, A., \& Hanna, S. (2012). Generative structures in cities. 8070:1-8070:18. http://sss8.cl/8070.pdf

Amr, A. I., Kamel, S., Gohary, G. E., \& Hamhaber, J. (2016). "Water as an ecological factor for a sustainable campus landscape", Procedia - Social and Behavioral Sciences, 216, 181-193. https://doi.org/10.1016/j.sbspro.2015.12.027

Asami, Y., Kubat, A. S., \& Istek, C. (2001). Characterization of the street networks in the traditional Turkish urban form. 21. https://doi.org/10.1068/b2718 
Azapagic, A., \& Perdan, S. (2000). "Indicators of sustainable development for industry", Process Safety and Environmental Protection, 78(4): 243-261. https://doi.or $\mathrm{g} / 10.1205 / 095758200530763$

Balsas, C. J. L. (2003). "Sustainable transportation planning on college campuses", Transport Policy, 10(1): 35-49. https://doi.org/10.1016/S0967-070X(02)00028-8

Berger, J. B., \& Braxton, J. M. (1998). "Revising Tinto's Interactionalist Theory Of Student Departure Through Theory Elaboration: Examining the Role of Organizational Attributes in the Persistence Process", Research in Higher Education, 39(2): 103-119.

Dalton, N. S. C. (2010). Synergy, Intelligibility and Revelation in Neighbourhood Places [PhD, University College London]. http://discovery.ucl.ac.uk/id/eprint/1334117

Dalton, R. C., \& Dalton, N. S. (2007). Applying Depth Decay Functions to Space Syntax Network Graphs. Applying Depth Decay Functions to Space Syntax Network Graphs. Proceedings of the 6th International Space Syntax Symposium, İstanbul. http://discovery.ucl.ac.uk/1113/1 /1113.pdf

Demiroğlu, D., Günaydın, A. S., Yücekaya, M., \& Çoban, A. (2018). Building Sustainable Transportation Model in University Campuses: Kilis 7 Aralık University. 705-715.

Dettlaff, W. (2014). Space syntax analysis - methodology of understanding the space. Ph.D. Interdisciplinary Journal, 283-291.

Dyson, R., \& Renk, K. (2006). "Freshmen adaptation to university life: Depressive symptoms, stress, and coping”, Journal of Clinical Psychology, 62(10), 1231-1244. https://doi.org /10.1002/jclp.20295

Gann, D. W. (2003). Spatial integration: A space syntax analysis of the villages of the Homol'ovi Cluster [PhD, The University of Arizona]. https://repository.arizona.edu/handle/10 $150 / 280412$

Gu, Y., Wang, H., Robinson, Z. P., Wang, X., Wu, J., Li, X., Xu, J., \& Li, F. (2018). "Environmental footprint assessment of green campus from a food-water-energy nexus perspective", Energy Procedia, 152, 240-246. https://doi.org/10.1016 /j.egypro.2018.09.109

Günerhan, S. A. (2016). Türkiye İçin Sürdürülebilir Üniversite Modeli. 5.

Hillier, B, Penn, A., Hanson, J., Grajewski, T., \& Xu, J. (1993). "Natural movement: Or, configuration and attraction in urban pedestrian movement", Environment and Planning B: Planning and Design, 20(1): 29-66. https://doi.org/10. 1068/b200029 
Hillier, B. (1998). "A Note on the Intuiting of From: Thre Issuen in the Theory of Desing", Environment and Planning B: Planning and Desing Anniversary Issue, 37-40.

Hillier, B. (1999). "The Hidden Geometry of Deformed Grids: Or, Why Space Syntax Works, When it Looks as Though it Shouldn't", Environment and Planning B: Planning and Design, 26(2): 169-191. https://doi.org/10.1068/b4125

Hillier, B. (2001). A theory of the city as object: Or, how spatial laws mediate the social construction of urban space. Presented at: 3rd International Space Syntax Symposium, Atlanta, Georgia, USA. May 2001. 3rd International Space Syntax Symposium, Atlanta, Georgia, USA. http://unde rtow.arch.gatech.edu/homepages/3sss/

Hillier, B. (2005). "The art of place and the science of space", World Architecture, 18: 96-102.

Hillier, B. (2007). Space is the machine: A configurational theory of architecture. Space Syntax. http://discovery.ucl.ac.u k/3881/1/SITM.pdf

Hillier, B., Burdett, R., Peponis, J., \& Penn, A. (1987). “Creating Life: Or, Does Architecture Determine Anything?", Arch. 8 Comport./Arch. Behav., 3(3): 233-250.

Hillier, B., Hanson, J., Peponis, J., Hudson, J., \& Burdett, R. (1983). "Space syntax, a different urban perspective", Architects Journal, 178: 47-63.

Hillier, B., \& Iida, S. (2005). Network and Psychological Effects in Urban Movement. In A. G. Cohn \& D. M. Mark (Eds.), Spatial Information Theory (Vol. 3693, pp. 475-490). Springer Berlin Heidelberg. https://doi.org/10.1007/11 556114_30

Hipp, J. A., Gulwadi, G. B., Alves, S., \& Sequeira, S. (2016). "The Relationship Between Perceived Greenness and Perceived Restorativeness of University Campuses and Student-Reported Quality of Life", Environment and Behavior, 48(10): 1292-1308. https://doi.org/10.1177/0 013916515598200

IAU. (1993). Kyoto Declaration on Sustainable Development. https://www.iauaiu.net/IMG/pdf/sustainable_developm ent_policy_statement.pdf

Jeong, S. K., Lee, T. H., \& Ban, Y. U. (2015). Characteristics of spatial configurations in Pyongyang, North Korea. Habitat International, 47, 148-157. https://doi.org/10.1016/j.ha bitatint.2015.01.010

Klarqvist, B. (1993). A space syntax glossary (Vol. 6). NA.

Kubat, A. S. (2015). Kentlerin Biçimsel Yapısımdaki Sayısal Mantı: Space Syntax. 32-58.

Kuo, F. E., \& Sullivan, W. C. (2001). "Environment and Crime in the Inner City: Does Vegetation Reduce Crime?", 
Environment and Behavior, 33(3): 343-367. https://doi.org/10.1177/0013916501333002

Legeby, A. (2013). Patterns of co-presence: Spatial configuration and social segregation. Architecture and the Built Environment, KTH Royal Institute of Technology.

Li, Y., Xiao, L., Ye, Y., Xu, W., \& Law, A. (2016). Understanding tourist space at a historic site through space syntax analysis: The case of Gulangyu, China. Tourism Management, 52: 30-43. https://doi.org/10.1016/j.tour man.2015.06.008

Litman, T., \& Burwell, D. (2006). "Issues in sustainable transportation", International Journal of Global Environmental Issues, 6(4). https://doi.org/10.1504/IJG ENVI.2006.010889

Lounsbury, J. W., \& DeNeui, D. (1996). "Collegiate psychological sense of community in relation to size of college/university and extroversion", Journal of Community Psychology, 24(4): 381-394. https://doi. org/10.1002/(SICI)1520-6629(199610)24:4<381::AIDJCOP7>3.0.CO;2-X

Lukman, R., Tiwary, A., \& Azapagic, A. (2009). "Towards greening a university campus: The case of the University of Maribor, Slovenia", Resources, Conservation and Recycling, 53(11): 639-644. https://doi.org/10.1016/j.resconrec.2 009.04.014

Miller, T. R., Muñoz-Erickson, T., \& Redman, C. L. (2011). "Transforming knowledge for sustainability: Towards adaptive academic institutions", International Journal of Sustainability in Higher Education, 12(2): 177-192. https://doi.org/10.1108/14676371111118228

Mohamad, Z. F., Kadir, S. N. A., Nasaruddin, A., Sakai, N., Mohamed Zuki, F., Hussein, H., Sulaiman, A. H., \& Mohd Salleh, M. S. A. (2018). "Heartware as a driver for campus sustainability: Insights from an action-oriented exploratory case study", Journal of Cleaner Production, 196, 1086-1096. https://doi.org/10.1016/j.jclepro.2018. 06.111

Oktaya, S. Ö., \& Küçükyağcl, P. Ö. (2015). Üniversite Kampüslerinde Sürdürülebilir Tasarım Sürecinin Irdelenmesi. Examination of Sustainable Design Process In University Campuses. 8.

Olszak, E. (2012). "Composite indicators for a sustainable campus-Design rationale and methodology: The case of the Catholic Institute of Lille", Ecological Indicators, 23, 573-577. https://doi.org/10.1016/j.ecolind.2012.05.021

Özbil, A., Özer, Ö., \& Kubat, A. S. (2013). "Sultanahmet Meydanı'nda hareket ve algı esaslı kentsel tasarım 
analizi", Mimarlık, 371. http://www.mimarlikdergisi.com /index.cfm?sayfa=mimarlik\&DergiSayi $=385 \&$ RecID=315 8

Özer, Ö., \& Sema, A. (2014). Walkability: Perceived and measured qualities in action. 17.

Park, H. T. (2009). Boundary Effects on the Intelligibility and Predictability of Spatial Systems. 86.

Patel, B., \& Patel, P. (2012). Sustainable campus of Claris lifesciences through green initiatives. Renewable and Sustainable Energy Reviews, 16(7), 4901-4907. https://doi.org/10.1016/j.rser.2012.03.062

Roberts, J., \& Styron, R. (2010). "Student satisfaction and persistence: Factors vital to student retention", Research in Higher Education Journal, 6(1): 18.

Rodwell, D. (2003). "Sustainability and the Holistic Approach to the Conservation of Historic Cities", Journal of Architectural Conservation, 9(1): 58-73. https://doi.or $\mathrm{g} / 10.1080 / 13556207.2003 .10785335$

Sayed, K. A., Hillier, B., Penn, A., \& Turner, A. (2014). Space Syntax Methodology. http://discovery.ucl.ac.uk/id/eprint/14150 80

Schiller, P. L., Bruun, E., \& Kenworthy, J. R. (2010). An Introduction to Sustainable Transportation: Policy, Planning and Implementation (1 edition). Earthscan Publications Ltd.

Tan, H., Chen, S., Shi, Q., \& Wang, L. (2014). "Development of green campus in China", Journal of Cleaner Production, 64, 646-653. https://doi.org/10.1016/j.jclepro.2013.10.019

Topçu, M. (2019). "Morphological Structures of Historical Turkish Cities", Iconarp International Journal of Architecture and Planning, 7(Special Issue 'Urban Morphology'): 212-229. https://doi.org/10.15320/ICO NARP.2019.86

Ugalde, C., Rigatti, D., Zampieri, F., \& Braga, A. (2009). Intelligibility in Large Spatial Systems The Case of Porto Alegre Metropolitan Region. Ref, 119: 1-13.

ULSF. (n.d.). Retrieved 16 January 2019, from http://ulsf.org/

UN-HABITAT. (2008). State of the World's Cities 2008/2009 Harmonious Cities. Earthscan.

Washington-Ottombre, C., Washington, G. L., \& Newman, J. (2018). "Campus sustainability in the US: Environmental management and social change since 1970", Journal of Cleaner Production, 196: 564-575. https://doi.org/10 .1016/j.jclepro.2018.06.012

Wey, W.-M., \& Huang, J.-Y. (2018). "Urban sustainable transportation planning strategies for livable City's 
quality of life", Habitat International, 82, 9-27. https://doi.org/10.1016/j.habitatint.2018.10.002

Zhang, L., Chiaradia, A., \& Zhuang, Y. (2013). In the intelligibility maze of space syntax- a space syntax analysis of toy models, mazes and labyrinths. 19.

\section{Resume}

Ahmet Salih Gunaydin is an Assistant Professor in the Faculty of Fine Arts and Design at Inonu University, Malatya. After he completed his master's degree at Ankara University in 2014, received his Ph.D. in Landscape Architecture from Cukurova University in 2018. The area of interest focuses on spatial configuration, conservation - development in historical environment, urban design, and space syntax.

Murat Yücekaya is working as an Assistant Professor at the Faculty of Engineering and Architecture, Department of Landscape Architecture at Nevşehir Haci Bektaş Veli University. He received his Ph.D. in Landscape Architecture from Cukurova University in 2017. His main research subjects are climate balanced urban design, urban heat island, microclimate simulations, and sustainable design. 